\title{
Decomposing the performance metrics of coconut cultivation in the South Indian States
}

\author{
Shine Raju Kappil (1) ${ }^{1}$, Ranjan Aneja (10 ${ }^{1 凶} \&$ Poonam Rani ${ }^{1}$
}

Coconut (Cocos nucifera) is extensively cultivated and used as a staple ingredient in Indian cuisines, especially in the South Indian cuisines. In India, other than edible purposes, coconut is widely used in religious practices and, it is considered as symbol of prosperity. Despite these facts, several upturns and downturns occurring in the growth trends of coconut in recent periods irrespective of geographical differences. This study attempts to decipher the growth trends in the area, the production and yield of coconut in major coconut producing states in India from 2000-2001 to 2017-2018. Kerala, Tamil Nadu and Karnataka are the states in India where coconut palms are extensively cultivated and produced in large quantities. These states together contribute to approximately 84 per cent of the total area for cultivation of coconut and account for over 87 per cent of total production in the country. We analyse the growth trends in coconut cultivation using appropriate growth equations to estimate the growth rates and instabilities in growth trends. Besides, we use decomposition analysis to find the role of area, price, yield and crop mix effects on coconut production. The results reveal that Karnataka secured high growth in coconut production and its productivity and recorded better acceleration but fluctuated heavily between the phases of years under investigation. It shows that the price effect and yield effect play a crucial role in the total change of coconut production among the selected states. Based on the results, we recommend the local governments and other dedicated authorities to ensure that coconut growers have better access to modern technology, quality inputs, marketing and credit facilities following local necessity. Eventually, these measures can attract and encourage many new farmers into coconut cultivation and thereby achieving better advances in coconut farming.

\footnotetext{
${ }^{1}$ Department of Economics, Central University of Haryana, Mahendergarh, Haryana, India. ${ }^{凶}$ email: ranjananeja@cuh.ac.in
} 


\section{Introduction}

oconut is a perennial crop with multifaceted uses in an ordinary person's day-to-day life and can be further put under process to generate various value-added products. Considering the coconut's economic value, small and marginal farmers focus on coconut cultivation in their lands (Naik, 2017). The coconut palms are widely found in the tropical and subtropical coastal regions globally and are called the 'Tree of life' because of their indispensable role in human life. As per the Food and Agriculture Organization (FAO) reports, coconuts grow in over 97 countries that spread over the major continents such as Asia, Africa, and America. Philippines and Indonesia are the leading coconut producers and contribute around 50 per cent of the total coconut produced globally (FAOSTAT, 2018). India stands third in coconut production with better productivity in nuts per hectare (Kalidas et al., 2014).

In India, states like Kerala, Tamil Nadu, and Karnataka have secured a top position by holding over two-thirds of the total production and area of coconut cultivation in the country (Coconut Development Board (CDB), 2020). India's government has been making adequate attempts to increase coconut production and ensure better and stable wholesale prices for coconut (Ministry of Agriculture \& Farmers Welfare (MoA and FW), 2020). CDB has adopted necessary initiatives to boost coconut growers' confidence and encourage farmers to cultivate coconut palms. It includes various policy schemes that provide training programmes, capacity building classes, technology-related services and financial assistance to facilitate the proliferation, aggregation of nuts, processing and value addition of coconut in the country $(\mathrm{CDB}, 2020)^{1}$. Coconut Producer Companies (CPCs) in targeted states aim to solve many of the coconut growers' problems (Veerakumaran and Vinaikumar, 2019). Government functionaries have played a crucial role in expanding coconut cultivation in states like Tamil Nadu, Karnataka, Andhra Pradesh, and other minor coconut-producing states (Lathika and Ajith Kumar, 2005). Through their initiatives, the government and other interest groups have contributed to visible hikes in coconut production and productivity in targeted states. We tried to analyse and trace the underlying variations and patterns associated with coconut farming's growth variables during the initial decades of the 21st century.

Coconut production has increased continuously with some fluctuations in Tamil Nadu and Karnataka and moderately in Kerala since the 1990s (Lathika and Ajith Kumar 2005; Elias, 2015; Maruthi and Peter, 2019). These positive developments might occur from various sources such as expansion in the area, changes in technology, price fluctuations, agricultural practices adopted, or the mixed impact of the two (Thamban et al., 2016). Estimates of CDB show a gradual increase in coconut cultivation in these states, but there are also fluctuations. Limited studies have attempted to analyse the growth dynamics associated with coconut cultivation and coconut production in the public domain. Most of those studies confined their objectives to just estimating the growth rates, and none of them tried to dig out the underlying patterns within it. Besides, it is necessary to check the instabilities in coconut growth variables, as these fluctuations will increase risks associated with coconut cultivation and force the farmers not to allocate higher investments into coconut farming.

Various economic agents are part of the coconut industry as these agents should understand the trends and fundamental changes occurring in the market to take suitable decisions. These agents include private buyers, CPCs, Mill owners, farmers, selfhelp groups, government and non-governmental stakeholders. These stakeholders may get ended up in unprecedented loss if they could not understand the growth developments taking place in the concerned and other interrelated sectors. Our study will benefit these agents in taking cautionary steps wherever required and using the investment opportunities opened up through coconut farming in these states. It demands holistic and higherlevel analysis, which accommodates the detailed analysis of growth variables associated with coconut cultivation. It is also necessary to dive into the factors contributing to the growth trends of coconut in the significant coconut-producing states in India. Growth rates of coconut in these states alone cannot guide us to coconut production's performance aspects. Application of decomposition analysis of coconut will help us cross-check the reliability of growth models of each state. In this context, the prime targets of this paper are:

1. To analyse the trends and performance of coconut cultivation among the selected states (from 2000-2001 to 2017-2018),

2. Determine the components responsible for the change in coconut output,

3. Examine the instabilities in growth trends of coconut.

\section{Review of literature}

There are few studies related to the growth aspects of coconut farming and its determinants at the international level. Muyengi et al. (2015) have tried to assess coconut farming and factors that affect coconut production in Tanzania. They find it that coconut tree per hectare and the number of extension services per year have a significant role in coconut production in Tanzania. Selvarajah and Geretharan (2013), with the help of the logit model, have found that age, farmland size, membership and active participation in organisational activities affect the adoption of modern coconut management practices in Sri Lanka. Herath and Wijekoon (2013) attempted to find the factors that affect organic coconut farming in Sri Lanka, and farmers' perception and attitude play a key role in adopting organic coconut farming. Omar and Fatah (2020) have found that agricultural practices, farmers' awareness, and socio-economic factors impact coconut farming's profitability in Malaysia.

In India, coconut cultivation has been escalating in the coastal regions as the net returns are well enough to fulfil farmers' demands. According to $\mathrm{CDB}$ statistics, coastal states such as Kerala, Tamil Nadu and Karnataka together contribute over 80 per cent in terms of both area and coconut production in India. Lathika and Kumar (2005) have expressed a positive rate of area expansion and coconut yield at the national level and in many new states. It reveals that the expansion period of coconut cultivation is not yet over in the country. Besides, the area effect plays a crucial role in output change in dominant coconut growing states except in Kerala from 1951 to 2002. They have opined that coconut production has increased because of the area expansion in Karnataka, whereas productivity enhancement contributed to states like Kerala and Tamil Nadu. According to Paul and Lakshmi (2015), the production trend has been growing gradually in the national market because of improved management of coconut cultivation, increased use of coconut products, and the sustainable increase in the price of coconut in the markets.

Existing research works have highlighted that Kerala had over 70 per cent share in the area devoted to coconut palms and more than 60 per cent share in coconut production in the country during the early fifties. However, other states such as Tamil Nadu and Karnataka had shown remarkable improvement in area and production during the later periods. Tamil Nadu and Karnataka have performed well in production and area under cultivation of coconuts over the past decades of the 20th century. The pace of 
growth in these states was gradual. However, in Kerala, coconut is the major crop from ancient history and is growing around 30 per cent of the total cropped area.

Decomposition analysis helps to know the relative contribution of coconut and coconut yield to India's coconut growing states' total output change. It has been widely used by researchers while analysing the growth performance of crops. Minhas and Vaidyanathan (1965) have pioneered a systematic technique of decomposition analysis of output growth. It is an additive decomposition method in which the total effect in output has sourced by four components, i.e., area, yield, crop-mix and interaction effect. This method of decomposition relies on absolute growth rates in the crop output. Parikh (1966) has applied another version of decomposition analysis that uses the multiplicative method, i.e., rely on agricultural products' relative growth rates. Afterward, many experts have come up with their decomposition analysis that has opted for either additive or multiplicative variants with minor modifications in their research works. Kakarlapudi (2012) has attempted to assess the measurement problems associated with various schemes of the decomposition analysis of crop output from Minhas and Vaidyanathan (1965) to Jamal and Zaman (1992) as there is any ambiguity regarding the choice of the most efficient method in the decomposition of output change. According to them, the multiplicative model developed by Jamal and Zaman (1992) is the most appropriate method to decompose, as it solves the issue of indexing and includes crucial components that influence the crop output. This multiplicative method of decomposition is superior, as it is free from residual effects. It measures the relative share of area, yield, price and crop-mix interaction in the total change in crop output.

Many research works highlight that crop output variations have an indispensable role while focusing on a particular crop's growth trends. Examining instability in growth variables associated with a crop will help bring out the unseen variations associated with it (Saima et al., 2017). Instability in a crop's growth trends can lead to adverse fluctuations in that crop's prices (Chand and Raju, 2008). It can badly affect the disposable income of the farmers who are cultivating the concerned crop. Keeping these facts in mind while analysing the recent growth trends in coconut cultivation, we also check variations in coconut production in the states. Experts like Ray (1983) have found that the states with higher growth rates and lowest instability indices are most desirable, whereas the states with lowest growth rates and highest instability indices are least desirable.

Though several studies have already made in the coconut literature, an analytical and rigorous approach to the performance of coconut growth aspects in Indian states selectively is limited in number. Most importantly, existing literature works on the growth trends of coconut crops in Indian states are confined to a period before the 21 st century whereas, this paper tries to analyse the growth trends of coconut in the prominent coconut producing states in the early phase of the 21 st century.

\section{Materials and methods}

Materials. We have selected three South Indian states namely Kerala, Tami Nadu, and Karnataka, for the analysis and excluded other South Indian regions based on data availability (See Fig. 1). The study uses cross-sectional data of coconut that encompasses 18 years (2000-2001 to 2017-2018). We have accessed the data from the Coconut Development Board on variables such as area (in hectares) under coconut cultivation, production (in Million nuts), productivity (nuts per hectare) and wholesale price (Indian rupees per quintal).
Methodological framework. Expansion and acceptance level for coconut cultivation has comprehended in the selected states through estimating growth rates in the area, production and yield of coconut in these regions. We have used the exponential growth equation to estimate the growth rates in the area, production, and coconut productivity. Compound growth rates computed using the exponential growth model. Many researchers used to estimate the growth trends of crops (Lathika and Ajith Kumar (2005); Kannan, 2012; Abid et al., 2014; Reddy et al., 2017; Preethi et al., 2018). This exponential model has been adopted with a prior belief that coconut output change in a selected year is the constant percentage of coconut output in the previous year (Boyce, 1987).

Estimation of patterns in growth. Patterns in growth rates of area, production and yield of coconut in the concerned states have examined whether the growth rates are accelerated or decelerated. Many researchers have fitted a log-quadratic trend for this purpose (Boyce, 1987; Ghosh, 2010; Obong et al., 2019). It exhibits the existence of some patterns if estimated exponential growth rates exhibit considerable variations. Prevalence of temporal fluctuations in exponential growth rates will violate the assumption of constant growth rate (assumed under exponential growth model) and instead signals the occurrence of acceleration or deceleration of growth over time (Boyce, 1987) Log-quadratic trend equation will be of the form:

$$
\operatorname{LnY}_{\mathrm{t}}=\mathrm{a}+\mathrm{bt}+\mathrm{ct}^{2}+\mathrm{u}_{\mathrm{t}}
$$

The positive $c$ value (ensure that it is significant with $t$ ratio) denotes accelerating growth, whereas the negative $c$ value denotes a deceleration of growth rate.

Decomposition analysis. We decompose the growth trends in coconut output into numerous components such as area, price, yield, crop mix and other interaction effects, which help the government and other concerned stakeholders identify suitable targets and policies. This paper has adopted a multiplicative method of decomposition analysis developed by Jamal and Zaman (1992). This decomposition analysis method is more appropriate than other similar models as it helps us decompose the output change into the area, yield, price, and crop-mix effects (Kakarlapudi, 2012). We can write this as:

$$
\begin{aligned}
& \ln \left(V_{t} / V_{o}\right)=\ln \left(A_{t} P_{t} Y_{t} a_{t} / A_{o} P_{o} Y_{o} a_{o}\right) \\
& \quad=\ln (\text { Area effect })+\ln (\text { price effect }) \\
& +\ln (\text { yield effect })+\ln (\text { crop }- \text { mix effect })
\end{aligned}
$$

Here $\ln ($ area effect $)=\ln \left(A_{\mathrm{t}} / A_{\mathrm{o}}\right)$

$$
\begin{aligned}
\ln (\text { price effect })= & 1 / 3 \ln \left(P_{t} Y_{t} a_{t} / P_{o} Y_{t} a_{t}\right)+1 / 3 \ln \left(P_{t} Y_{o} a_{o} / P_{o} Y_{o} a_{o}\right) \\
+ & 1 / 6 \ln \left(P_{t} Y_{o} a_{t} / P_{o} Y_{o} a_{t}\right)+1 / 6 \ln \left(P_{t} Y_{t} a_{o} / P_{o} Y_{t} a_{o}\right) \\
\ln (\text { Yield effect })= & 1 / 3 \ln \left(P_{t} Y_{t} a_{t} / P_{t} Y_{o} a_{t}\right)+1 / 3 \ln \left(P_{o} Y_{t} a_{o} / P_{o} Y_{o} a_{o}\right) \\
+ & 1 / 6 \ln \left(P_{t} Y_{t} a_{o} / P_{t} Y_{o} a_{o}\right)+1 / 6 \ln \left(P_{o} Y_{t} a_{t} / P_{o} Y_{o} a_{t}\right) \\
\ln (\text { Crop - mix effect })= & 1 / 3 \ln \left(P_{t} Y_{t} a_{t} / P_{t} Y_{t} a_{o}\right)+1 / 3 \ln \left(P_{o} Y_{o} a_{t} / P_{o} Y_{o} a_{o}\right) \\
& +1 / 6 \ln \left(P_{t} Y_{o} a_{t} / P_{\mathrm{t}} Y_{o} a_{o}\right)+1 / 6 \ln \left(P_{o} Y_{t} a_{t} / P_{o} Y_{t} a_{o}\right)
\end{aligned}
$$

where; $A=$ Gross cropped area of all crops in the state. $Y=$ Yield per hectare. $P=$ Wholesale price/minimum support price of Milling or Ball copra (Rupees per quintal). $a=$ Proportion of cropped area for coconut cultivation. $t=$ Terminal period. $o=$ Base period

Instability index. Cuddly Della Valle Index (CDVI) has chosen to compute the instability in coconut growth trends as it is superior to various other methods such as coefficient of variation, 


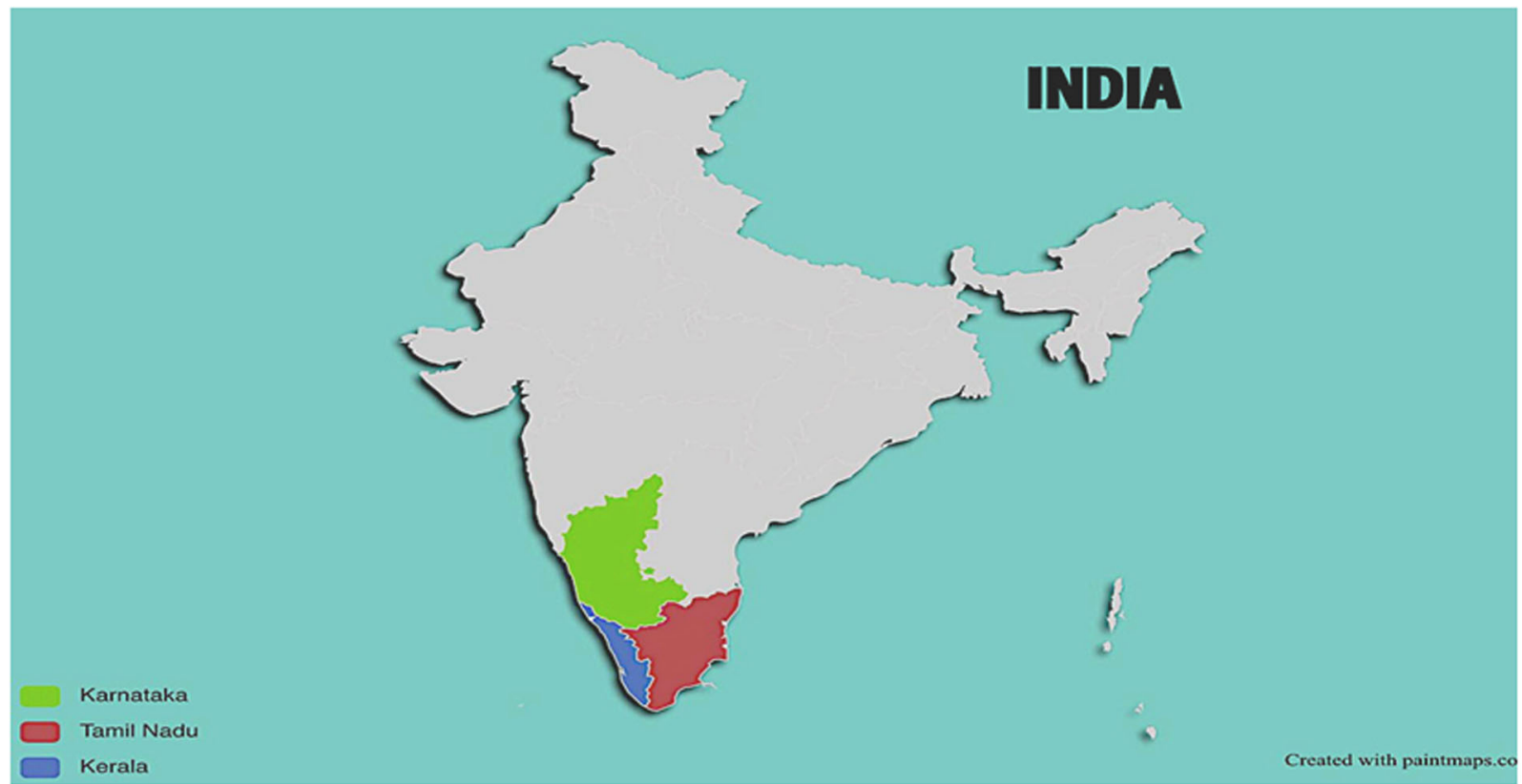

Fig. 1 Map of the study states. This map shows the three states in South India, i.e., Kerala (Blue), Tamil Nadu (Red) and Karnataka (Light green), where coconut palms grow extensively. The study excludes Andhra Pradesh as the data is unavailable due to its separation into two states during the study period. (source of the map: map of India with disputed territories created with paintmaps.com and can be used freely).

Table 1 Share of major coconut cultivated states in India.

\begin{tabular}{|c|c|c|c|c|c|c|c|}
\hline \multirow[t]{3}{*}{ States } & \multirow[t]{3}{*}{ Coconut area as per cent of net sown area (2014) } & \multicolumn{6}{|c|}{ Percentage share of states } \\
\hline & & \multicolumn{3}{|l|}{ Area } & \multicolumn{3}{|l|}{ Production } \\
\hline & & 2000-01 & 2009-10 & 2017-18 & 2000-01 & 2009-10 & 2017-18 \\
\hline Tamil Nadu & 9.65 & 17.73 & 20.57 & 21.05 & 25.18 & 34.1 & 25.3 \\
\hline Karnataka & 5.12 & 18.3 & 22.1 & 24.72 & 13.83 & 13.82 & 26.37 \\
\hline Others & 53.4 & 13.22 & 15.76 & 15.74 & 17.32 & 15.2 & 12.82 \\
\hline
\end{tabular}

(Values are in Percentage).

dispersion, Coppock Instability index (Sanjay and Kundu, 2018; Kolar et al., 2020). The study has created CDVI for the area, production, and coconut yield at selected states in India. This instability index can de-trend the concerned series and provide an exact direction of instability, and it is free from the problem of overestimation. CDVI de-trends the coefficient of variation [CV] by using adjusted R2 or coefficient of variation.

Cuddy Della Valle index (in per cent $)=\mathrm{CV} \times$ Square Root of $1-\mathrm{Ad} . R^{2}$

$$
\begin{aligned}
\mathrm{CV} & =\text { Coefficient of variation }(\text { in per cent }) \\
& =(\text { Standard deviation } / \text { Mean }) \times 100
\end{aligned}
$$

Here Ad. $R^{2}$ is the adjusted value of the coefficient of determination from the time trend regression. A low value of CDVI, i.e., between 0 and 15, shows lesser instability in the area, production, and coconut yield during the period under concern. CDVI value greater than 15 and less than 30 indicates there is medium instability in the series. The value of CDVI greater than 30 depicts that fluctuations are very high in the series considered.

Detailed understanding of the instability associated with growth trends in coconut requires to divide the entire period, i.e., 2000-2001 to 2017-2018, into two sub-periods, viz 2000-2001 to 2008-2009 and 2009-2010 to 2017-2018. We decided to divide the total period of the past 18 years into two sub-periods to check whether there is any instability in coconut growth among the states under concern.

\section{Results and discussions}

At the outset, an effort has been made to understand coconut's growth trends in India and selected coconut growing states during the early phase of the 21 st century. Table 1 reveals that the country's southern states, namely Kerala, Tamil Nadu and Karnataka, hold a remarkable position in coconut cultivation.

In India, three south Indian states account for 84.26 per cent of the Indian coconut area in 2017, against 86.78 per cent in 2000 . Coconut production in these states together accounts for 87.18 per cent of the Indian coconut area against 82.68 per cent in 2000 . Though there is a slight reduction in the area-wise cultivation of coconut over the study period, coconut production in these states together has increased. Many researchers have pointed out that Kerala's supremacy in coconut cultivation has been deteriorating gradually since the 1980s. As found in the contemporary research works, Kerala's supreme and unique dominance concerning the 


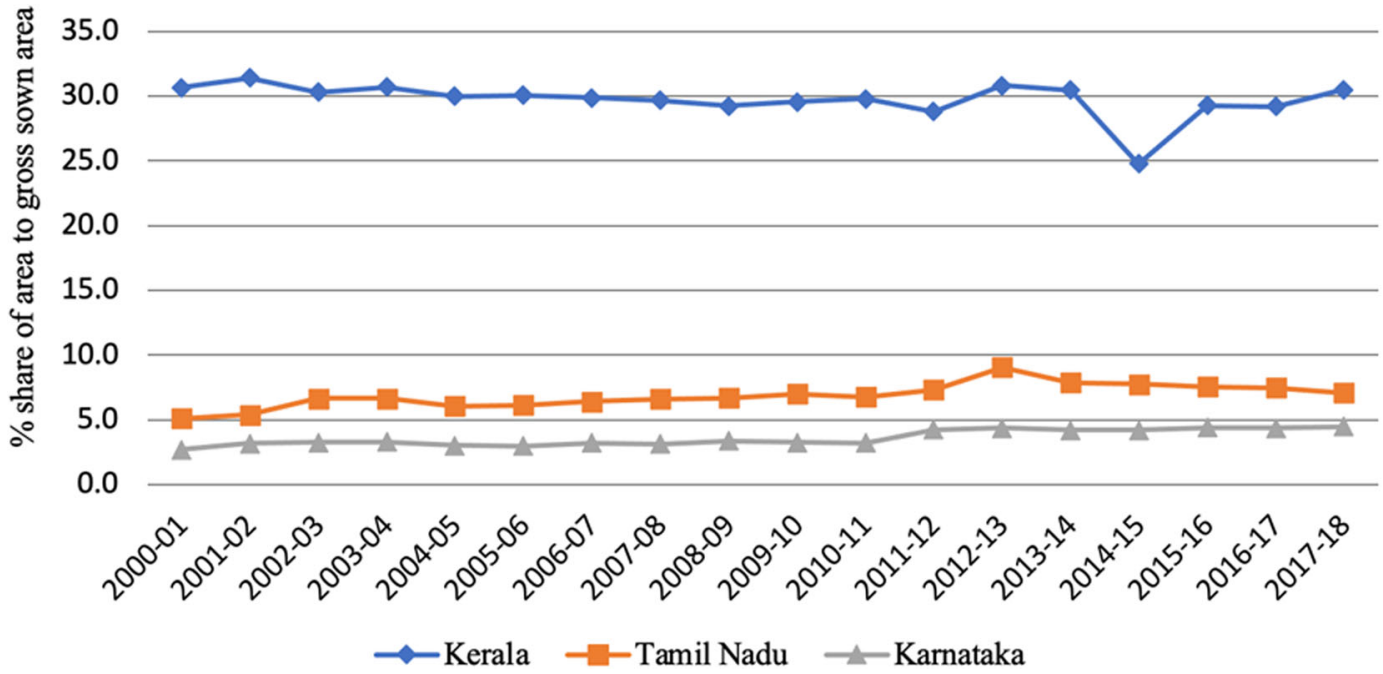

Fig. 2 Contribution of coconut in the gross sown area (GSA) in selected states. This graph shows the percentage share of area devoted by Kerala, Tamil Nadu and Karnataka for coconut cultivation to each state's gross sown area during the agricultural years under consideration (Source: calculated based on data retrieved from Coconut Development Board and Reserve Bank India).

Table 2 Exponential growth and acceleration or deceleration trends.

\begin{tabular}{lllcccr} 
States & $\begin{array}{l}\text { Growth } \\
\text { rate (area) }\end{array}$ & $\begin{array}{l}\text { Acceleration/ } \\
\text { deceleration }\end{array}$ & $\begin{array}{l}\text { Growth rate } \\
\text { (production) }\end{array}$ & $\begin{array}{l}\text { Acceleration/ } \\
\text { deceleration }\end{array}$ & $\begin{array}{l}\text { Growth rate } \\
\text { (yield) }\end{array}$ & $\begin{array}{l}\text { Acceleration/ } \\
\text { deceleration }\end{array}$ \\
\hline Kerala & $-1.405^{\star}$ & 0.001 & $1.397^{\star}$ & 0.002 & $2.802^{\star}$ & 0.001 \\
Tamil Nadu & $2.219^{\star}$ & 0.000 & $5.488^{\star}$ & $-0.004^{\star}$ & $3.270^{\star}$ & $-0.004^{\star \star}$ \\
Karnataka & $2.708^{\star}$ & 0.000 & $10.844^{\star}$ & $0.005^{\star \star \star}$ & $8.136^{\star}$ & $0.005^{\star \star \star}$ \\
\hline $\begin{array}{l}{ }^{*} p<0.01,{ }^{* \star} p<0.05^{* \star *} p<0.1 \\
\text { (Values are in Percentage) }\end{array}$ & & & & \\
\hline
\end{tabular}

area of cultivation and production of coconut have been declining even in the early phase of the 21st century, and the results of Fig. 1 were in line with the above findings. This gradual stagnancy has attributed to various reasons, including conversion of palm gardens to commercial plots, unprecedented volatility in coconut prices (Shanthini and Ramane, 2018), Incidence of diseases and pests, lack of adoption of technology (Preethi et al., 2018), acute shortage of labour inputs and increased cost of production (Elias, 2015). However, Table 1 and Fig. 1 reveal that Tamil Nadu and Karnataka have shown significant advances during the study period compared to the stepping-back performance of the state of Kerala. Karnataka manifests a spectacular performance concerning increasing the area and production of coconut compared with the other two states under concern.

India shows a gradual increase in the area under cultivation of coconut since the 1990s (CDB, 2020; FAO, 2013). However, Kerala, known to be the land of coconuts, has registered negative growth during this period (Elias, 2015). There are chances of area expansion in other major coconut growing states, i.e., in Tamil Nadu and Karnataka. Figure 2 describes the percentage share of area under cultivation of coconut in the three states respective to their individual Gross Sown Area (GSA) from 2000 to 2017. It is visible that Kerala is showing back-and-forth motion in terms of the share of coconut area under cultivation to its total GSA. On the other hand, Tamil Nadu and Karnataka have given more interest to coconut cultivation because their share in the area under cultivation of coconut respective to their GSA has been increasing gradually. It depicts that farmers in Tamil Nadu and Karnataka are coming forward to cultivate coconut in their land, realising the economic value and increases the popularity of coconut-based value-added products.
When the estimated growth rates have compared with the estimated growth rates of coconut during the past periods, there are temporal variations in coconut growth trends (Lathika and Ajith Kumar, 2005). It exhibits the chances for acceleration or deceleration in growth rates over time. An appropriate trend equation has fitted to examine the underlying patterns in coconut area growth, production, and yield rate in dominant coconut growing states in India, and Table 2 states the results. It reveals that from 2000-2001 to 2017-2018 coconut production and yield rise at exponential rates of 1.397 per cent and 2.802 per cent per annum and significant at 1 per cent level in Kerala. However, exponential growth in coconut area during the same period is negative (significant at 1 per cent level) though there is an acceleration in the growth rate of coconut area in Kerala. In Tamil Nadu and Karnataka, the growth rate in area, production and yield rate is positive and significant. However, we observed significant deceleration for coconut production and yield in Tamil Nadu. Among the states, Karnataka obtained the highest growth in the area, production and yield rate in coconut during the study period.

Karnataka has experienced a better acceleration in terms of production and yield of coconut during the study period. The above findings are in line with recent work on the growth trends in Karnataka (Maruthi and Peter, 2019). This acceleration in production and productivity of coconut in Karnataka result from favourable climatic conditions during the first decade of the 21st century and the establishment of the National Horticulture Mission (NHM) in 2006. NHM has introduced various crop improvement schemes and better management and disease control measures for coconut growers in Karnataka. (Kishore and 
Murthy, 2016). Tamil Nadu showed a deceleration in terms of production and yield of coconut during the study period.

Analysis of area, production, and yield in India's selected states merely explains the growth pattern and direction of change. It cannot confirm the influence of area expansion and productivity on the total variation in coconut production. Thus, it is beneficial to adopt a decomposition analysis to understand the factors that push the output growth. We have tried to decompose the relative share of area, yield, price, and crop-mix effects in coconut output in India's three selected states.

Area effect attempts to bring out how expansion in area under cultivation of coconut in Indian states impact the growth trends in coconut output. The price effect investigates the impact of price fluctuations or variations on the coconut output over the years. The yield effect tells us how the productivity of coconut palms influences the coconut output in these states whereas, the Crop-mix effect traces how the practice of inter/mixed crop cultivation in coconut fields at different points of time affects the coconut output. When compared between all the four effects, the crop-mix effects have a distinct meaning here. Coconut, being a perennial crop, opens up the scope for practising inter/mixed crop cultivation between the coconut palms. Coconut growers in the selected states cultivate pulses (horse gram, cowpea, groundnut), tubers (yam, colocasia, tapioca), spices and condiments (ginger, clove, pepper, turmeric) and fruit plants (papaya, banana, pineapple, cocoa) as inter/mixed crops in coconut fields. These crops have a shorter life cycle and duration of maturity compared to coconut palms.

Table 3 shows that the yield effect is positive in all the states, and Karnataka recorded the highest yield effect (41.82 per cent). Area effect has no impact on the overall growth in coconut output among any of the states investigated and found to be negative. This negative sign of the area effect depicts that area under coconut cultivation is not a responsible factor for the increment in coconut production in any of these states during the entire study period. Though the area under cultivation of coconut has increased throughout the study period in Tamil Nadu and Karnataka, its proportion is meagre compared with other crops in these states. Figure 1 shows that per cent of coconut area to their respective GSA in these states is less (less than 8 per cent) throughout the period without too many spikes. Predominately Kerala has a sizeable land contributed for coconut in GSA and, this has been more or less constant throughout the period except in few agricultural years. Altogether it concludes that area expansion had shown few downward fluctuations during the period, which ultimately resulted in deterioration of the role of area effect on the growth output of coconut in these states.

The decomposition analysis results in Table 3 show that there exists a positive price effect in all states and, Kerala has the highest price effect on coconut output ( 82.10 per cent). The Crop-mix effect is reported highest in Tamil Nadu (23.72 per cent) and reported negative in Kerala. Though the price effect and yield effect are the substantial sources for the coconut output change in all the states, the price effect has contributed the highest to the coconut output during the study period. Among the three states, total effects on coconut output were highest in Karnataka (1.99 per cent) during the study period. The study has also applied decomposition analysis for the different periods within the study period (see Appendix). In Tamil Nadu and Kerala, the area effect has contributed positively to the increase in coconut output during the recent periods. It shows that the price effect is a crucial source in Kerala and Tamil Nadu's output growth in successive periods. However, the yield effect and crop-mix effect are the major contributors to the coconut output in Karnataka.

Cuddy Della Valle instability index helps to analyse the instability within the growth variables of the crop. Table 4 shows instability in the area, production and coconut yield during the sub-periods and entire period. Fluctuations in the coconut area, production and yield rate are lower for Kerala in both the phases and for the whole study period (CDVI less than 15 per cent considered as lower instability). It infers that coconut growers in Kerala have considerable opportunities to receive better profits from coconut farming, as there are slight fluctuations in coconut output and productivity. Overall, the variations in coconut area, production and yield in Kerala have increased in phase II.

Tamil Nadu has shown lower instability in the area, production, and coconut yield for the entire study period. It is visible from the table that coconut production and its yield rate in Tamil Nadu have shown medium-high instability during phase 1 but have

Table 3 Sources of coconut output in selected states in India from 2000 to 2017.

\begin{tabular}{llllll} 
States & Total effect & Area effect & Price effect & Yield effect & Crop-mix effect \\
\hline Kerala & 1.62746 & $-0.13174(-8.10)$ & $1.336086(82.10)$ & $0.560284(34.42)$ & $-0.13717(-8.42)$ \\
Tamil Nadu & 1.310828 & $-0.01687(-1.28)$ & $0.693147(52.87)$ & $0.323591(24.69)$ & $0.310956(23.72)$ \\
Karnataka & 1.994191 & $-0.0617(-3.10)$ & $0.781514(39.20)$ & $0.834191(41.82)$ & $0.440186(22.08)$ \\
\hline $\begin{array}{l}\text { Fractions. } \\
\text { (Values in bracket are in percentage). }\end{array}$ & & & \\
\hline
\end{tabular}

Table 4 Instability index of coconut in states.

\begin{tabular}{|c|c|c|c|c|c|c|c|c|c|}
\hline States & Phase I & Phase II & Overall & Phase I & Phase II & Overall & Phase I & Phase II & Overall \\
\hline Kerala & 2.58 & 6.54 & 5.12 & 4.45 & 14.04 & 11.3 & 3.29 & 9.96 & 8.16 \\
\hline Karnataka & 2.27 & 6.11 & 5.01 & 18.78 & 22.89 & 31.05 & 18.78 & 20.16 & 26.86 \\
\hline
\end{tabular}


reduced to a considerable level during phase II. On the other hand, fluctuations in the area of coconut cultivation increased in phase II.

It is visible from the table that the instability index for coconut production and yield rate in Karnataka are alarmingly high, whereas the area instability index was very low for the entire period. Instability in coconut production is very high as CDVI was 31,05 per cent for the whole period. Overall, we must note that fluctuations in area, production and yield of coconut have increased in phase II.

Variable-wise analysis for the states shows that the area instability index ballooned in phase II from phase I, but it was very low for the entire period. Production and yield instability index has increased rapidly in phase II for Kerala and Karnataka but reduced for Tamil Nadu drastically. Production and yield instability indices are higher compared to area instability indices. Tamil Nadu and Kerala have achieved lower instability in coconut growth than Karnataka and, more specifically, Tamil Nadu achieved a better position as the fluctuations in coconut production and yield have decreased considerably in phase II.

It shows that though Karnataka has shown higher growth rates in the area, production and productivity of coconut than other states, it also has reported higher instabilities during the study period. Tamil Nadu and Kerala have also shown medium-level fluctuations for coconut growth variables during the study period and within the sub-periods examined. It is not a favourable situation for coconut cultivation as it can demotivate the coconut growers to continue with coconut farming in the future and divert their attention to other crops. It is necessary to introduce various schemes to reduce the instabilities in coconut production and productivity as it can maintain the strong wave for coconut farming in states like Tamil Nadu and Karnataka.

Many often, fluctuations in coconut palms' production and productivity are affected by climate variations, pest attacks, poor agricultural practices, lack of suitable fertilisers, and manures. Farmer collectives and other interest groups can do a lot to solve many of the above problems faced by coconut growers. As part of the institutional reforms, $\mathrm{CDB}$ has been putting efforts to establish CPC for a village or few villages and collectivise all coconut growers residing in those villages as $\mathrm{CPC}$ members. $\mathrm{CDB}$ has begun this initiative in 2013 and, this movement has got good feedback and support in Kerala, whereas limited in other states. CPC members are given access to good seedlings at affordable rates, subsidised fertilisers and manures, training modules and access to better agricultural practices associated with coconut farming. These facilities provided by $\mathrm{CDB}$ through $\mathrm{CPC}$ can solve fluctuations in growth variables of coconut to a great extent. Moreover, establishing more CPCs in states such as Karnataka, Tamil Nadu will help the individual farmers and $\mathrm{CDB}$ to come closer to each other and facilitate easy access to initiatives put forward by CDB. It helps CDB formulating newer policies and initiatives in these states to promote coconut growers and coconut farming.

\section{Conclusion}

The paper has attempted to understand and analyse the growth pattern of coconut major coconut growing states in India during the early phase of the 21 st century. The yield effect and price effect play an indispensable role in the output growth of coconut in all the major coconut cultivating states during the study period. Area effect has been negative in all the selected states, which depicts that area expansion in coconut cultivation is merely nominal for other crops in these states. Instability analysis using CDVI indicates that these states showed fluctuating growth trends in the area, production and yield of coconut, and Karnataka reported a high level of instability in coconut production and its productivity. Karnataka has a better growth rate in the area, production and yield during the study period with significant acceleration over time than other states. It predicts that Karnataka has a promising future in coconut cultivation among the supreme coconut-grown states in India. Meanwhile, concerned stakeholders have to adopt necessary measures to boost the growth engine of coconut cultivation, especially in Kerala.

Based on the results, we suggest a few policy recommendations. First, more initiatives are necessary to increase coconuts' productivity and production in Kerala and Tamil Nadu. Respective governments have to take adequate steps to encourage new farmers and existing farmers to enter into coconut cultivation. It requires the mediation of local self-groups or CPCs who have better acquaintances with the local farmers. Second, coconut growers have provided technical support and quality seedlings for better yield and seek measures to reduce pest attacks on palms. Third, the promotion of inter-cropping and crop diversification in palm fields will be a better option to earn diversified income. It will ensure repeated care and protection to the coconut palms from the farmers' side. Fourth, we recommend the concerned stakeholders provide better marketing facilities and ensure fair prices for the coconuts. Connecting coconut growers with the CPCs will help farmers to increase their bargaining capacity and eliminate exploitation from intermediaries and private buyers in the coconut industry. It will eradicate the malpractices such as hoarding practised by private buyers to a great extent and price-related fluctuations in the coconut market. Finally, respective stakeholders and governments with abundant coastal plains must formulate policies to organise various awareness programmes on coconut farming and provide creditrelated services to coconut growers to enter coconut cultivation.

Meanwhile, this study has few limitations concerning temporal and spatial aspects. First, this study focuses only on three major coconut-producing states in India. Second, we have used timeseries data that generally restrict to accommodate spatial aspects. Besides, few variables such as technical factors, coconut exports are not included in the study, as the statistics are unavailable for the entire study period. We recommend it to widen this study into a substantial level covering more coconut cultivating states and countries and get the attention of respective stakeholders for better prospects of the coconut industry. Our study's growth models also have great applicability and scope to analyse other crop markets' growth trends.

\section{Appendix: Sources of coconut output growth (period-wise)}

\begin{tabular}{|cccccr}
\hline & $\begin{array}{l}\text { Total } \\
\text { effect }\end{array}$ & $\begin{array}{l}\text { Area } \\
\text { effect }\end{array}$ & $\begin{array}{l}\text { Price } \\
\text { effect }\end{array}$ & $\begin{array}{l}\text { Yield } \\
\text { effect }\end{array}$ & $\begin{array}{l}\text { Crop-mix } \\
\text { effect }\end{array}$ \\
\hline Kerala & & & & & \\
2000-2001 to 2004-2005 & 0.63 & -0.009 & 0.604 & 0.065 & -0.031 \\
2005-2006 to 2009-2010 & -0.225 & -0.096 & -0.099 & 0.117 & -0.147 \\
2010-2011 to 2014-2015 & 0.636 & -0.008 & 0.887 & -0.05 & -0.193 \\
2015-2016 to 2017-2018 & 0.214 & 0.006 & 0.079 & 0.083 & 0.046 \\
Tamil Nadu & & & & & \\
2000-2001 to 2004-2005 & 0.017 & -0.073 & 0.074 & -0.083 & 0.099 \\
2005-2006 to 2009-2010 & 0.311 & -0.221 & 0.22 & 0.125 & 0.187 \\
2010-2011 to 2014-2015 & 0.388 & 0.049 & 0.165 & -0.003 & 0.176 \\
2015-2016 to 2017-2018 & 0.159 & 0.029 & 0.154 & 0.016 & -0.041 \\
Karnataka & & & & & \\
2000-2001 to 2004-2005 & 0.238 & 0.042 & 0.568 & -0.515 & 0.144 \\
2005-2006 to 2009-2010 & 0.128 & -0.012 & -0.52 & 0.576 & 0.084 \\
2010-2011 to 2014-2015 & 1.696 & -0.06 & 0.969 & 0.581 & 0.207 \\
2015-2016 to 2017-2018 & -0.18 & -0.039 & -0.342 & 0.217 & -0.015 \\
\hline
\end{tabular}

(Fractions)

Source: Author's calculation using Jamal and Zaman model (1994)

\section{Data availability}

The datasets analysed during this study are compiled from various sources and are available on request. The datasets were 
derived from the following public domains: https://www. coconutboard.gov.in/Statistics.aspx; and https://www.indiastat. com/Home/Datasearch?Keyword=Coconut; https://doi.org/ 10.7910/DVN/TJNCEC.

Received: 13 August 2020; Accepted: 13 April 2021;

Published online: 12 May 2021

\section{Note}

1 Some of the notable initiatives of CDB are Friends of Coconut Tree [FoCT], Coconut Palm Insurance Scheme [CPIS], Kera Suraksha Insurance Scheme [CTC], Neera Technician Training Programme [NTTP] and Technology Mission on Coconut [TMoC]. FoCT collectivizes coconut tree climbers in coconut growing states, CPIS extends insurance coverage for coconut palms and CTC provides insurance coverage to coconut climbers. NTTP provides training modules for the production of Neera-a value-added product from coconut. TMoC provides funds to set up processing units for value addition.

\section{References}

Abid S, Shah NA, Hassan A, Farooq A, Masood MA (2014) Growth and trending area, production and yield of major crops of Khyber Pakhtunkhwa, Pakistan. Asian J Agric Rural Dev 4(2):149-155

Boyce JK (1987) Agrarian impasse in Bengal: Institutional constraints in technological change. Oxford University Press, Oxford, England

Chand R, Raju SS (2008) Instability in Andhra Pradesh agriculture-a disaggregates analysis. Agric Econ Res Rev 21:283-288

Coconut Development Board (2020) Schemes of CDB. https://www.coconutboard. gov.in/presentation/scheme.htm. Accessed 15 Dec 2020

Elias G (2015) Trends in the area of coconut cultivation in India. Indian J Res 4 (6):120-122

Food and Agricultural Organisation of the United Nations (2013) Report of the high-level expert consultation on coconut sector development in Asia and the Pacific region. FAO Office for Asia and Pacific and Asia Pacific Coconut Community, Thailand

FAOSTAT Statistical Database (2018) Food and Agricultural Organisation of the United Nations, Rome. http://faostat.org/. Accessed 15 Aug 2020

Ghosh BK (2010) Growth and variability in the production of crops in West Bengal Agriculture. Trends in Agric Econ 3(3):135-146

Herath CS, Wijekoon R (2013) Study on attitudes and perceptions of organic and non-organic coconut growers towards organic coconut farming. Investigations 31(2):5-14

Jamal H, Zaman A (1992) Decomposition of growth trend in agriculture: another approach. Indian J Agric Econ 47(4):644-652

Kakarlapudi KK (2012) Decomposition analysis of agricultural growth: a review of measurement issues. Munich Personal RePEc Archive MPRA Paper no. 35873, Munich

Kalidas K, Darthiya M, Malathi P, Thomas L (2014) Organic Coconut cultivation in India-Problems and prospects. Int J Sci Res 3(6):14-15

Kannan E (2012) Trends in India's agricultural growth and its determinants. Asian J Agric Dev 8(2):79-99

Kishore MS, Murthy C (2016) Growth in area, production and productivity of coconut in Karnataka. Int J Comm Business Manag 9(2):156-162

Kolar P, Awasthi PK, Sahu A (2020) Growth performance of oilseeds among leading states in India. Economic Affairs 65(2):219-224

Lathika M, Ajith Kumar CE (2005) Growth trends in area, production and productivity in India. Indian. J Agric Econ 60(4):686-697

Ministry of Agriculture and Farmers Welfare (2020, June 23) Government declares Minimum Support Price for Mature Dehusked Coconut [Press release]

Minhas BS, Vaidyanathan A (1965) Growth of crop output in India 1951-54 to 1958-61: an analysis by component elements. J Indian Soc Agric Statist 17 (2):230-252

Maruthi I, Peter P (2019) A comprehensive study on the issue of coconut production in Karnataka. http://www.isec.ac.in/Final\%20report\%20coconut.pdf. Accessed 12 July 2020

Muyengi ZE, Msuya E, Lazaro E (2015) Assessment of factors affecting coconut production in Tanzania. J Agric Econ Dev 4(6):83-94
Naik NJ (2017) Growth trends in area, production and productivity of coconut in major growing countries. IOSR J Humanit Soc Sci 22(9):47-56

Obong A, Akpan E, Otung AI (2019) Growth rate analysis for domestic production and import of Beer of Barley in Nigeria. Middle East J Agricre Res 8(1):21-27

Parikh A (1966) State-wise growth rate in agricultural output- An econometric analysis. Artha Vijnana $8(1): 1-52$

Omar Z, Fatah FA (2020) Unravelling the factors affecting agriculture profitability enterprise: evidence from coconut smallholder production. Accounting 6:493-500

Paul R, Lakshmi (2015) Emerging trend analysis of coconut production in India. Sai Om J Comm Manag 4:6

Preethi VP, Thomas KJ, Kuruvila A (2018) Performance of coconut in India: a trend analysis. J Tropical Agric 56(2):210-214

Ray SK (1983) An empirical investigation of the nature and causes for growth and instability in Indian agriculture: 1950-80. Indian J Agric Econ 38(4):459-474

Reddy VK, Immanuelraj KT (2017) Area, production and yield trends and patterns of oilseeds growth in India. Econ Affairs 62(2):327. 334

Saima R, Habib N, Raza I, Zahra N (2017) Estimating compound growth rate, instability index and annual fluctuation of cotton in Pakistan. Asian J Agric Rural Dev 7(4):86-91

Sanjay SM, Kundu KK (2018) Growth and instability in cotton cultivation in Northern India. Econ Affairs 63(2):433-440

Selvarajah V, Geretharan T (2013) Factors that influence the adoption of improved coconut management practices in Batticaloa district: a logit model approach. In: Proceedings of the Third International Symposium. Oluvi, Sri Lanka, pp. $17-20$

Shanthini G, Ramane RV (2018) An analysis of growth trends of coconut crop in India. Int J Res Manag Econ Comm 8(3):78-85

Thamban C, Jayasekhar S, Chandran KP, Jagnathan D (2016) Coconut production in Kerala- trends, challenges and opportunities. Indian Coconut J 49 (4):10-15

Veerakumaran G, Vinaikumar E (2019) Problems and prospects of coconut producer organisations in Kerala- An exploratory study. SMART J Business Manag Stud 15(1):68-73

\section{Author contributions}

SRK, RA and PR did the write-up and then analysed the results. All authors read the paper and made necessary corrections prior to submission. All the authors read and approved the final paper.

\section{Competing interests}

The authors declare no competing interests.

\section{Additional information}

Correspondence and requests for materials should be addressed to R.A.

Reprints and permission information is available at http://www.nature.com/reprints

Publisher's note Springer Nature remains neutral with regard to jurisdictional claims in published maps and institutional affiliations.

Open Access This article is licensed under a Creative Commons Attribution 4.0 International License, which permits use, sharing, adaptation, distribution and reproduction in any medium or format, as long as you give appropriate credit to the original author(s) and the source, provide a link to the Creative Commons license, and indicate if changes were made. The images or other third party material in this article are included in the article's Creative Commons license, unless indicated otherwise in a credit line to the material. If material is not included in the article's Creative Commons license and your intended use is not permitted by statutory regulation or exceeds the permitted use, you will need to obtain permission directly from the copyright holder. To view a copy of this license, visit http://creativecommons.org/ licenses/by/4.0/

(C) The Author(s) 2021 